\title{
Predation by an Amazonian Giant Centipede (Scolopendra gigantea) on a Baker's Cat-eyed Snale (Leptodeira bakeri)
}

\author{
Gerard van Buurt ${ }^{1}$ and Haroen Dilrosun ${ }^{2}$ \\ ${ }^{1}$ Kaya Oy Sprock, 18, Curaçao (gvanbuurt@gmail.com) \\ ${ }^{2}$ Bosweg 7a, Julianadorp, Curaçao
}

$\mathrm{O}^{n}$ Aruba on 2 January 2017, Dr. H. Dilrosun observed an Amazonian Giant Centipede (Scolopendra gigantea), about $18 \mathrm{~cm}$ in length, attack a Baker's Cat-eyed Snake (Leptodeira bakeri). These centipedes, which occur through-

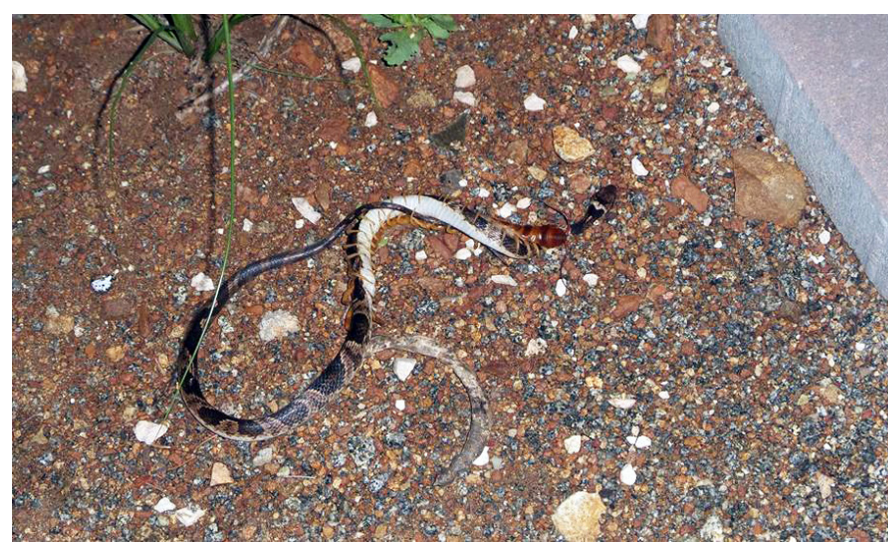

Fig. 1. A Baker's Cat-eyed Snake (Leptodeira bakeri) attacked, killed, and eaten by an Amazonian Giant Centipede (Scolopendra gigantea) on Aruba. Photograph by Dr. H. Dilrosun. out northern South America and some continental islands, can reach lengths to $30 \mathrm{~cm}$ (Shelley and Kiser 2000). They are known to consume a variety of invertebrate prey and small vertebrates, including frogs, lizards, snakes, birds, and mammals; large individuals are known to climb cave ceilings and catch bats (Molinari et al. 2005). Baker's Cat-eyed Snakes, locally known as "Santanero," occur on Aruba and in northeastern Venezuela (Mijares-Urrutia et al. 1995). The snake died about half an hour after initially observed, after which the centipede began to eat it.

\section{Literature Cited}

Mijares-Urrutia, A., A.L. Markezich, and A. Arends R. 1995. Hallazgo de Leptodeira bakeri Ruthven (Serpentes: Colubridae) en la Peninsula de Paraguaná, noroeste de Venezuela; con comentarios diagnósticos y biológicos. Caribbean Journal of Science 31: 77-82.

Molinari, J., E.E. Gutiérrez, A.A. de Ascenção, J.M. Nassar, A. Arends, and R.J. Márquez. 2005. Predation by Giant Centipedes, Scolopendra gigantea, on three species of bats in a Venezuelan cave. Caribbean Journal of Science 41: 340-346.

Shelley, R.M. and S.B. Kiser. 2000. Neotype designation and a diagnostic account for the centipede, Scolopendra gigantea L. 1758, with an account of S. galapagoensis Bollman 1889 (Chilopoda Scolopendromorpha Scolopendridae). Tropical Zoology 13: 159-170. 